\title{
11. ANALYSIS OF SEDIMENTARY FACIES USING BULK MINERALOGICAL CHARACTERISTICS OF CRETACEOUS TO QUATERNARY SEDIMENTS FROM THE KERGUELEN PLATEAU: SITES 737, 738, and 7441
}

\author{
Gerhard Bohrmann ${ }^{2}$ and Werner U. Ehrmann²
}

\begin{abstract}
Carbonate-free portions of Upper Cretaceous to Holocene sediment samples from the Kerguelen Plateau in the southern Indian Ocean were investigated by X-ray diffraction. Downhole variations in the content of opal-A, opal-CT, quartz, feldspar, barite, and clinoptilolite were studied at Site 737 on the northern Kerguelen Plateau and at Sites 744 and 738 on the southern Kerguelen Plateau. The variation of these components reflects temporal changes in the depositional history of the Kerguelen Plateau as well as major differences in the sedimentary evolution between the northern plateau and the southern plateau.

Carbonate is the dominant component in the pelagic sediments on the Kerguelen Plateau. In addition, biogenic opal sedimentation plays an important role throughout most of the sequence. A major increase in opal accumulation is documented at all sites in late Miocene time, which is in accordance with the well-known increase in silica productivity probably caused by a major cooling step. Because of its position near the Polar Frontal Zone, sediments from Site 737 show a more extensive opal deposition than at Sites 744 and 738. An earlier productivity pulse is documented at Site 744 on the southern plateau within the early Oligocene, following the initial phase of intense East Antarctic glaciation. This cooling event resulted in higher amounts of ice-rafted terrigenous quartz and, to a lesser extent, feldspar. With the exception of the Site 744 sediments, opal deposition in Paleogene and older sediments can be reconstructed only from the diagenetic transformation products of opal-CT and probably clinoptilolite. In contrast to the southern sequence, on the northern Kerguelen Plateau higher amounts of clinoptilolite and no opal-CT were found. These major differences in the diagenetic environments may be due to extensive volcanism in the northern area. The volcanic influence at Site 737 is well recorded by the higher feldspar content and higher amounts of volcanic glass shards.
\end{abstract}

\section{INTRODUCTION}

The Kerguelen Plateau is the world's largest submarine plateau, about $2500 \mathrm{~km}$ in length and $200-600 \mathrm{~km}$ in width, stretching from $46^{\circ}$ to $64^{\circ} \mathrm{S}$ and $60^{\circ}$ to $84^{\circ} \mathrm{E}$ in a generally northwestsoutheast direction (Fig. 1). Cretaceous to Quaternary sediments from the Kerguelen Plateau were analyzed for bulk sediment mineralogy of the carbonate-free fraction in order to investigate the depositional and diagenetic history of the sediments. Site 737 was used as the reference site on the northern Kerguelen Plateau. Deposits from the southern tip of the Kerguelen Plateau were studied in a composite profile including sediments at Sites 744 and 738 . Our objective was to compare bulk mineralogical data from the sediment sequences of both the north and south parts of the submarine plateau, which are separated by more than $10^{\circ}$ latitude from each other.

Site 737 on the northern plateau is at $50^{\circ} 13.67^{\prime} \mathrm{S}, 73^{\circ} 01.95^{\prime} \mathrm{E}$, in a water depth of $564 \mathrm{~m}$ (Fig. 1). Site 738 was drilled at $62^{\circ} 42.54^{\prime} \mathrm{S}, 82^{\circ} 47.25^{\prime} \mathrm{E}$, on the southern tip of the Kerguelen Plateau in $2252 \mathrm{~m}$ water depth. In order to recover a more complete or more extended Eocene through Holocene section on the southern Kerguelen Plateau, Site 744 was cored in 2307 m water depth at $61^{\circ} 34.66^{\prime} \mathrm{S}, 80^{\circ} 35.46^{\prime} \mathrm{E}, 250 \mathrm{~km}$ north-northwest of Site 738 (Fig. 1). Both sediment sequences are within the Antarctic Zone, which is bounded by the Polar Front to the north and the Continental Water Boundary to the south (Whitworth, 1988). The northern Site 737 is close to the Polar Front, which represents the southern limit of the Polar Frontal Zone. The Polar Frontal Zone marks the circumpolar current, which is the

\footnotetext{
${ }^{1}$ Barron, J., Larsen, B., et al., 1991. Proc. ODP, Sci. Results, 119: College Station, TX (Ocean Drilling Program).

2 Alfred-Wegener-Institut für Polar- und Meeresforschung, Columbusstraße, D-2850 Bremerhaven, FRG.
}

major oceanographic feature that separates the antarctic coldwater sphere from the warmer Subantarctic Zone. The southern sediment sequence documented at Sites 738 and 744 lies north of the Antarctic Divergence and thus may document changes of this oceanographic front through time.

\section{MATERIAL AND METHODS}

Bulk mineralogical data were obtained on selected samples of the carbonate-free sediment fraction by X-ray diffraction (XRD). After freeze-drying, the samples were treated with hydrogen peroxide and acetic acid to remove both organic matter and carbonate. Carbonate-free samples were mechanically ground and mixed with an internal standard of corundum $\left(\alpha-\mathrm{Al}_{2} \mathrm{O}_{3}\right)$ at a ratio of $2: 1$. Further grinding in an agate vial under acetone enhanced homogenization. Randomly oriented, pressed-powder slides were X-rayed from $2^{\circ}$ to $50^{\circ} 2 \theta$ with a speed of $0.005^{\circ} 2 \theta / \mathrm{s}$ using a Philips PW 1729 generator and $\mathrm{CoK}_{\alpha}$ radiation with an automatic divergence slit and an automatic sample changer.

In order to quantify the quartz content of the sediments, the ratio of the d(101) quartz peak height (at $3.343 \AA$ ) to the d(012) corundum peak height (at $3.479 \AA$ ) was calculated. The absolute amount of quartz was then estimated from a standard curve based on 11 mixtures of different amounts of quartz with a monomineralic matrix of smectite.

To measure the content of biogenic opal, we followed the XRD method of Eisma and van der Gaast (1971). Because both biogenic opal and volcanic glass show a broad, diffuse reflection band as a result of their amorphous structure, some problems of overlap exist. Therefore, we have not calculated opal-A values in samples containing noticeable amounts of volcanic glass.

Because a general calibration curve of clinoptilolite could not be established due to strong changes in d-spacing intensities by chemical variations (Boles, 1972), we give only the ratio of the intensity of the $(020)$ clinoptilolite lattice to the intensity of 


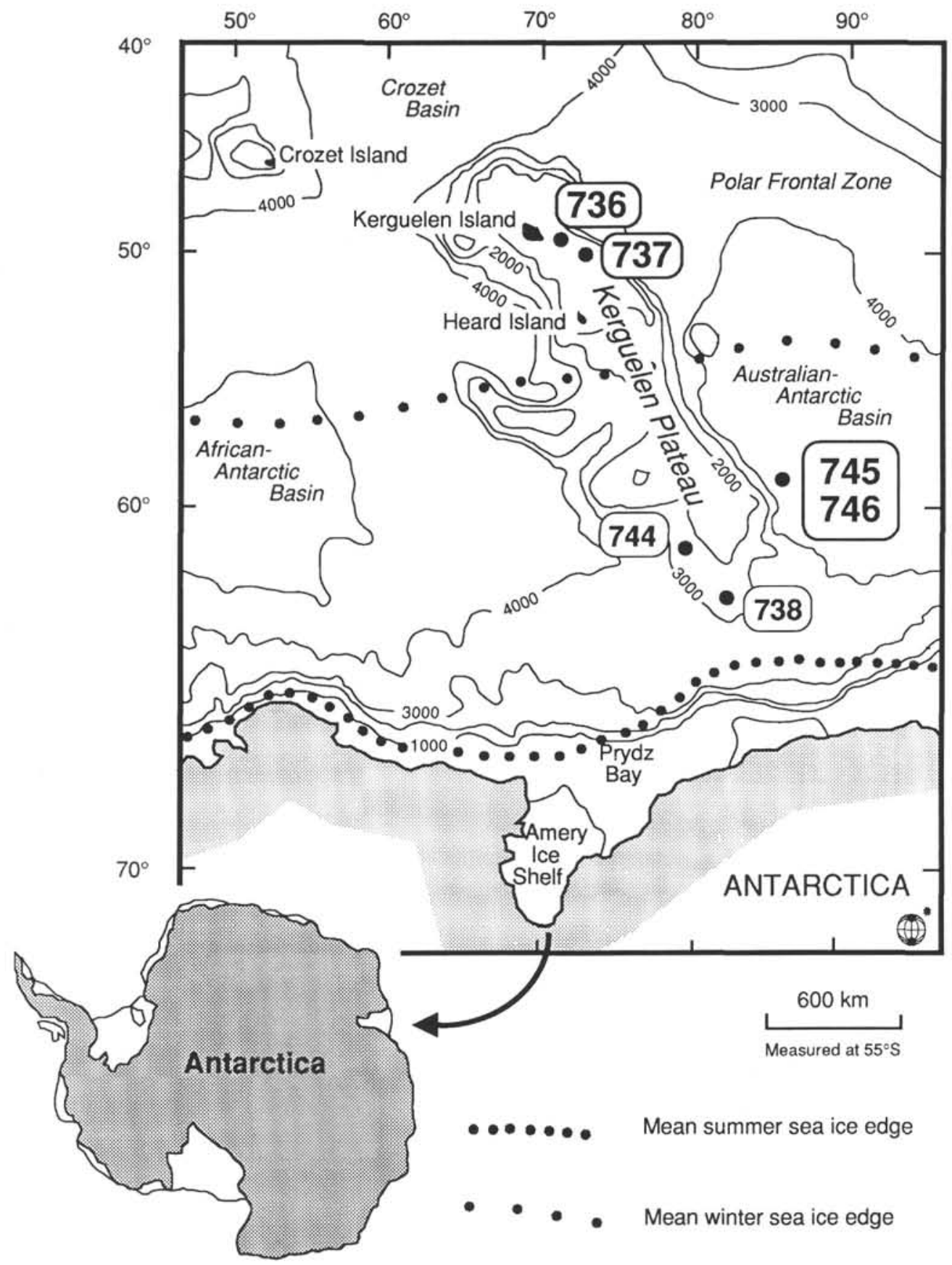

Figure 1. Location of ODP Leg 119 Sites 737, 738, and 744 on the Kerguelen Plateau in the southern Indian Ocean.

the internal standard. Semiquantitative estimates of feldspar, opal-CT, and barite are also given by peak height ratios to that of the internal standard $(\mathrm{d}(012)$ corundum peak at $3.479 \AA)$. We used the feldspar reflection at $3.20 \AA$, the $d(101)$ spacing of opal-CT between 4.02 and $4.11 \AA$, and the d(121) lattice of barite at $3.103 \AA$.

Carbonate data were taken from Ehrmann (this volume), including shipboard analyses (Barron, Larsen, et al., 1989).

\section{LITHOLOGIC SEQUENCES AND STRATIGRAPHY}

\section{Site $\mathbf{7 3 7}$}

Six lithologic units were described at Site 737 (Barron, Larsen, et al., 1989). The uppermost Unit I ( $0-1.5 \mathrm{~m}$ below seafloor [mbsf]) consists of Quaternary mixed glauconitic sand and diatom ooze, overlying a 239-m-thick sequence of upper Miocene to lower Pliocene diatom ooze (Unit II; $1.5-240 \mathrm{mbsf}$ ). In lithologic Unit III (240-306 mbsf), the carbonate content increased as a result of the higher amounts of calcareous nannofossils, which changed the dominant sediment type to diatom-calcareous nannofossil ooze (Figs. 2 and 3). At 263 mbsf a hiatus covering the time interval $8.2-10 \mathrm{Ma}$ was found (Barron, Larsen, et al., 1989). Unit IV (306-321 mbsf) is a stratigraphically condensed sequence in the middle Miocene consisting of a turbiditic sandy siltstone and calcareous nannofossil ooze with high amounts of volcanic components. The boundary of the underlying unit is thought to be accompanied by a major hiatus covering the interval from 15 to $23 \mathrm{Ma}$. Below this hiatus, a thick 


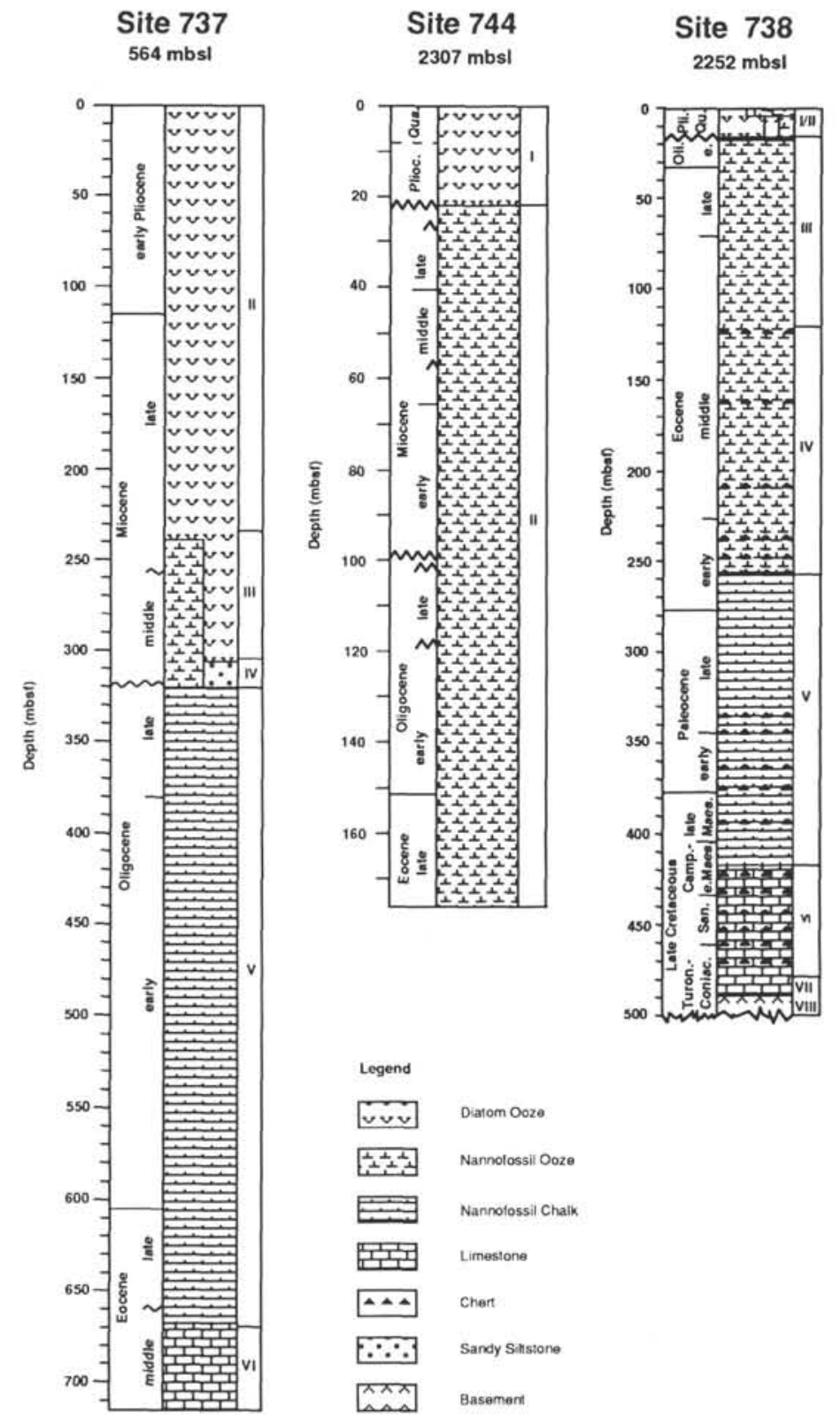

Figure 2. General lithology and lithologic units of the stratigraphic record at ODP Sites 737, 738, and 744 .

calcareous claystone unit (Unit V; 321-668 mbsf) with variable amounts of carbonate (Fig. 3) was cored. This hemipelagic upper Eocene to upper Oligocene sequence shows a lot of redeposition, although coarse-grained particles were not found in higher amounts (Barron, Larsen, et al., 1989). The lowest lithologic Unit VI, from 668 to $711 \mathrm{mbsf}$, is composed of middle Eocene pelagic clayey limestone containing some chert layers.

\section{Sites 744 and 738}

On the southern Kerguelen Plateau the Oligocene-Holocene sequence is best documented at Site 744; however, the section older than Oligocene is well represented at Site 738. Sediments at Site 744 were subdivided into two lithologic units (Barron, Larsen, et al., 1989). The upper $23 \mathrm{~m}$ (Unit I) is an uppermost Miocene to Quaternary diatom ooze with variable amounts of pelagic carbonate particles (Figs. 2 and 4). Below a hiatus that spans the interval from 4.2 to $5.6 \mathrm{Ma}$ (Baldauf and Barron, this volume), a thick pelagic unit of nannofossil ooze (Unit II; 23$176 \mathrm{mbsf}$ ) was cored, representing latest Eocene to late Miocene sedimentation. In comparison, the Oligocene to Quaternary sediment sequence at Site 738 is quite incomplete. Quaternary to uppermost Miocene diatom ooze (Unit I; 0-16.8 mbsf) and upper Miocene nannofossil ooze (Unit II; $16.8-17.7 \mathrm{mbsf}$ ) overlie a thick (17.7-120 mbsf) sequence of lower Oligocene to middle Eocene homogeneous nannofossil ooze (lithologic Unit III). The underlying Unit IV at Site 738 (121-254 mbsf) is composed of middle and lower Eocene nannofossil chalk and ooze containing nodular cherts (Figs, 2 and 5). The lower Eocene to Maestrichtian section is composed of chalk containing chert nodules (Unit V; 254-418 mbsf). Silicified Campanian to Turonian lime- 


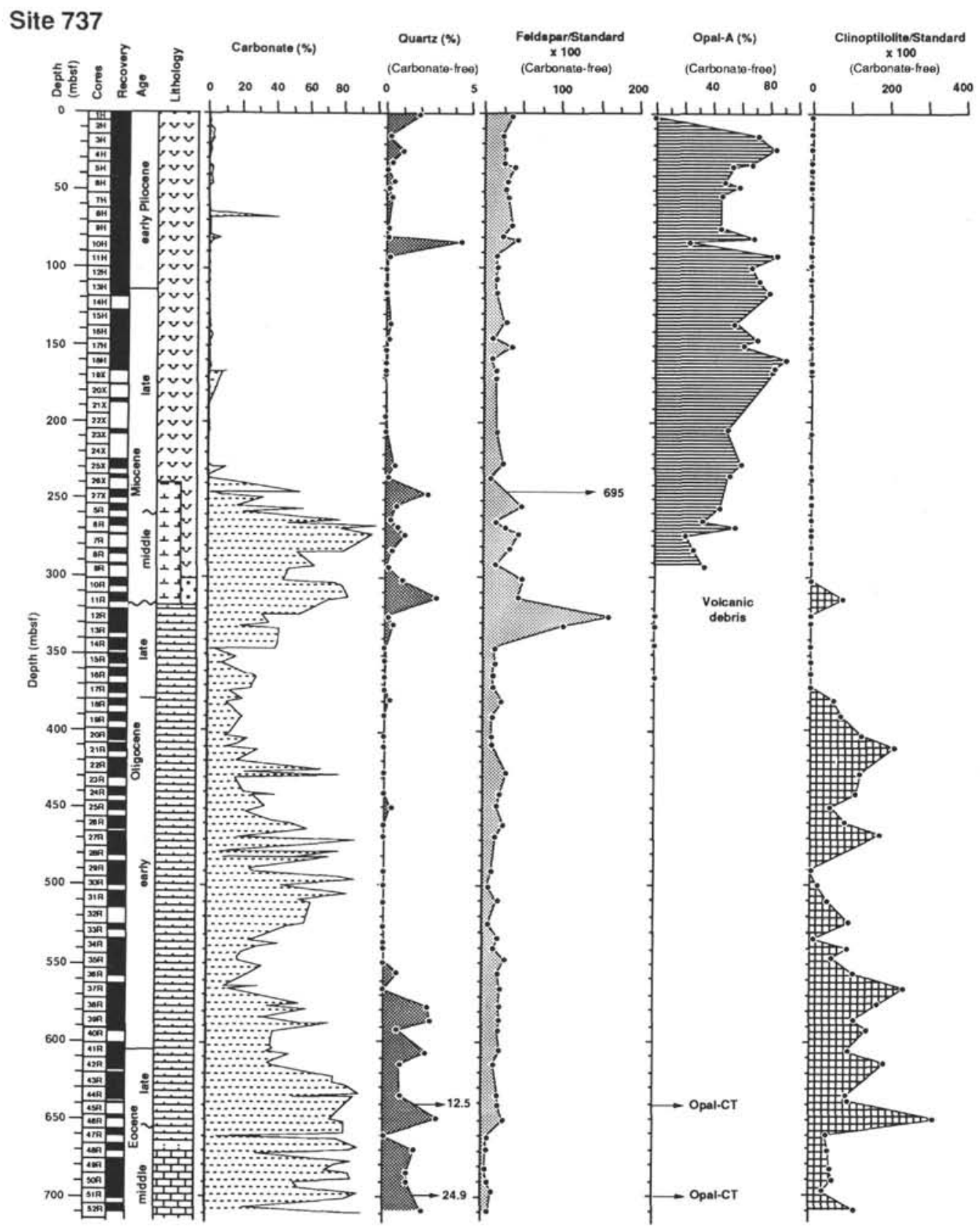

Figure 3. Lithology, age, carbonate content, and results from XRD investigations at Site 737. The semiquantitative patterns of the mineralogical data were calculated on a carbonate-free basis. Quartz contents were calculated using calibration curves. Feldspar is given by the ratio of the $3.2 \AA$ peak to the $(012)$ corundum peak $\times 100$. The clinoptilolite pattern is based on the ratio of $\mathrm{I}_{(020) \text { clinoptilolite }}$ to $\mathrm{I}_{(012) \text { corundum }} \times 100$.

stone (Figs. 2 and 5; Unit VI; 418-480 mbsf) follows downcore. Intercalated between this pelagic unit and the volcaniclastic rocks and altered basalts of the basement (Unit VIII) is a thin clastic limestone unit (Unit VII; 480-495 mbsf; Barron, Larsen, et al., 1989).

\section{RESULTS}

Clay minerals and carbonates and in some intervals opal-A are the dominant components of the sediment analyzed. Based on the XRD analyses we identified quartz, feldspar, opal-A, opal-CT, clinoptilolite, barite, and sporadic pyrite. Absolute contents of quartz and opal-A and relative abundances of the other minerals were obtained (Figs. 3 through 5 and Appendix Tables 1 through 3 ).

\section{Site 737}

At Site 737 quartz, feldspar, opal-A, and clinoptilolite were detected in higher amounts (Appendix Table 1) in the carbonate-free sediment fraction (Fig. 3). Barite reflections, which were observed in the sediments from Sites 744 and 738, were not detected.

The small amounts of opal-CT found in two intervals (119737B-45R-1, 15-19 cm, and 119-737B-51R-1, 50-52 cm) are related to the Eocene chert layers (Fig. 3). These chert samples are 


\section{SITE 744}

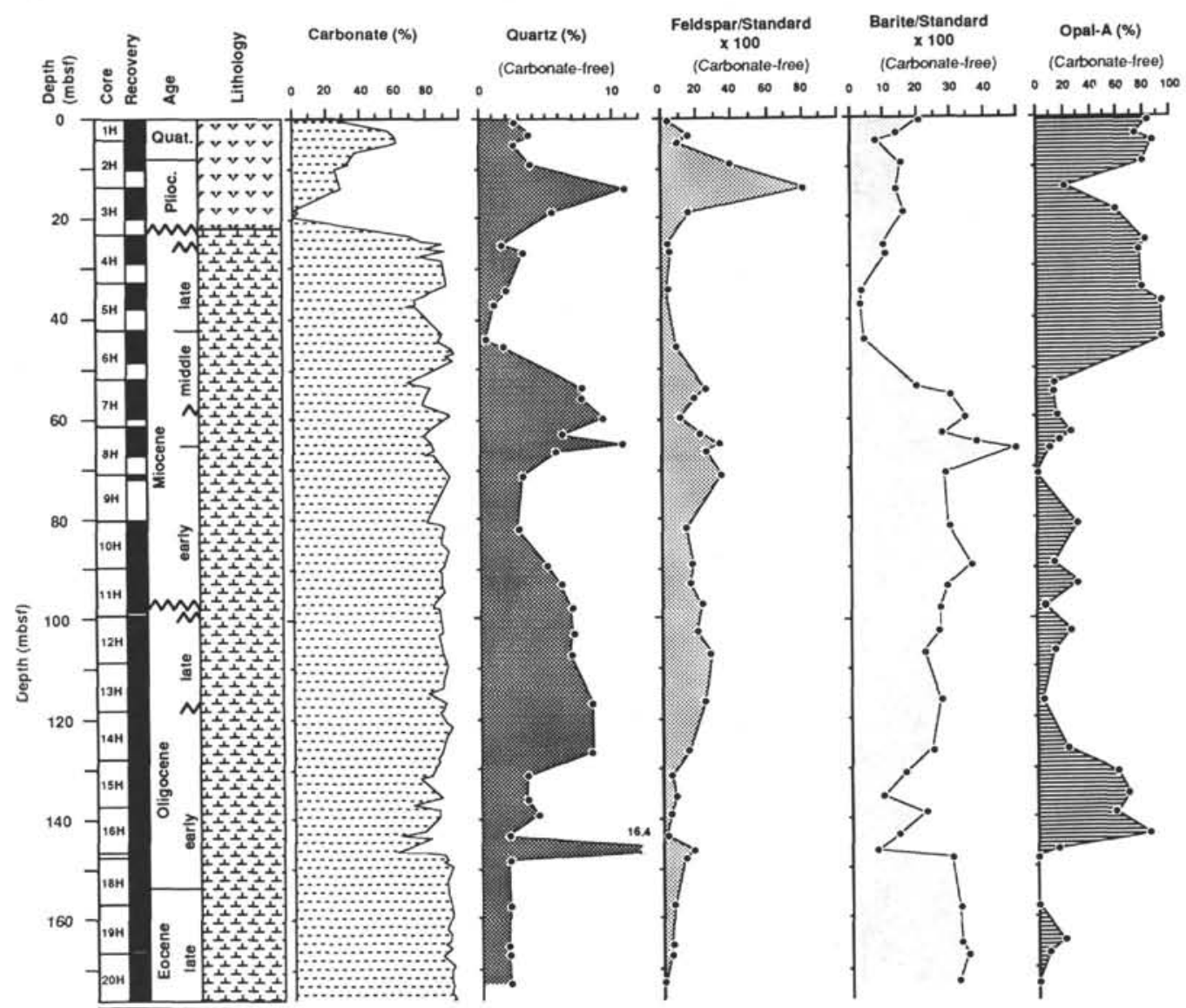

Figure 4. Lithology, age, carbonate content, and results from XRD investigations at Site 744. The semiquantitative patterns of the mineralogical data were calculated on a carbonate-free basis. Opal- $\mathrm{A}$ and quartz contents were calculated using calibration curves. Feldspar is given by the ratio of the $3.2 \AA$ peak to the (012) corundum peak $\times 100$. Barite was calculated by the ratio of $I_{(121) \text { barite }}$ to $I_{(012) \text { corundum }} \times 100$.

also characterized by quartz contents of $12.5 \%$ and $24.9 \%$, respectively (Fig. 3). Apart from these diagenetic beds, quartz contents are consistently lower than $1 \%$ of the carbonate-free sediment. Higher quartz contents occur in variable amounts from 550 mbsf downcore (lowermost Oligocene through Eocene), between 250 and 320 mbsf (middle Miocene), and within the uppermost $70 \mathrm{~m}$ (Fig. 3).

Feldspar reflections were observed throughout the sedimentary column (Fig. 3). Higher intensity ratios $\left(\mathrm{I}_{\text {feldspar }} / \mathrm{I}_{\text {corundum }}\right)$ reflecting higher amounts of feldspar are present between Cores 119-737A-27X and 119-737B-13R (247-324 mbsf; Appendix Table 1). This interval correlates well with the middle Miocene interval of enhanced quartz content (Fig. 3).

More than $50 \%$ biogenic opal (opal-A) in the carbonate-free portion was usually detected in the uppermost $290 \mathrm{~m}$. In some intervals contents up to $90 \%$ were measured (Fig. 3). From a maximum content at $160 \mathrm{mbsf}$, biogenic opal decreases downhole to $20 \%-30 \%$ of the carbonate-free fraction. This decrease in the opal content is even more striking, if the opal content of the bulk sample is considered, because of the downhole dilution by biogenic carbonate, which starts at $230 \mathrm{mbsf}$ (Fig. 3). Below Core 119-737B-9R we cannot estimate the opal-A content because volcanic glass is present in higher amounts. Deeper than 300 mbsf biogenic silica was found by microscopic examination only in small amounts (Barron, Larsen, et al., 1989). The high biogenic opal contents and high amounts of volcanic glass are also reflected by high dissolved silica concentrations in the pore water at Site 737 (Barron, Larsen, et al., 1989).

Clinoptilolite reflections are present in nearly all XRD samples from lithologic Units V and VI from deeper than $380 \mathrm{mbsf}$. Average intensity ratios $\left(\mathrm{I}_{\text {clinoptilolite }} / \mathrm{I}_{\text {corundum }}\right)$ are about 100 and maximum values up to 330 were sporadically encountered. Clinoptilolite was also found in Sample 119-737B-11R-2, 48-50 $\mathrm{cm}$, from Unit IV (Fig. 3).

\section{Sites 744 and 738}

At Sites 744 and 738, quartz, feldspar, and barite were found throughout the Upper Cretaceous to Holocene sediment sequence, whereas opal-A, opal-CT, and clinoptilolite were found only in some intervals of the sediment sequence. With some exceptions within the upper Miocene section (Site 744; Fig. 4), quartz contents are consistently higher than $2 \%$ in the carbonate-free fraction. At Site 738, the lowermost $250 \mathrm{~m}$ of sediments overlying basement rocks contains enhanced amounts of quartz. The maxima of up to $28.7 \%$ (Fig. 5) are related to chert layers. The high concentration of $19.5 \%$ quartz in Sample 119-738B$3 \mathrm{H}-1,125-129 \mathrm{~cm}$, occurs in a section with a low sedimentation rate, above the hiatus at $18 \mathrm{mbsf}$, which separates lower Oligocene from upper Miocene sediments.

At Site 744 , the carbonate-free sediment is characterized by higher but more strongly fluctuating quartz contents than those analyzed at Site 738 (Fig. 4). Maxima of up to about $10 \%$ quartz 


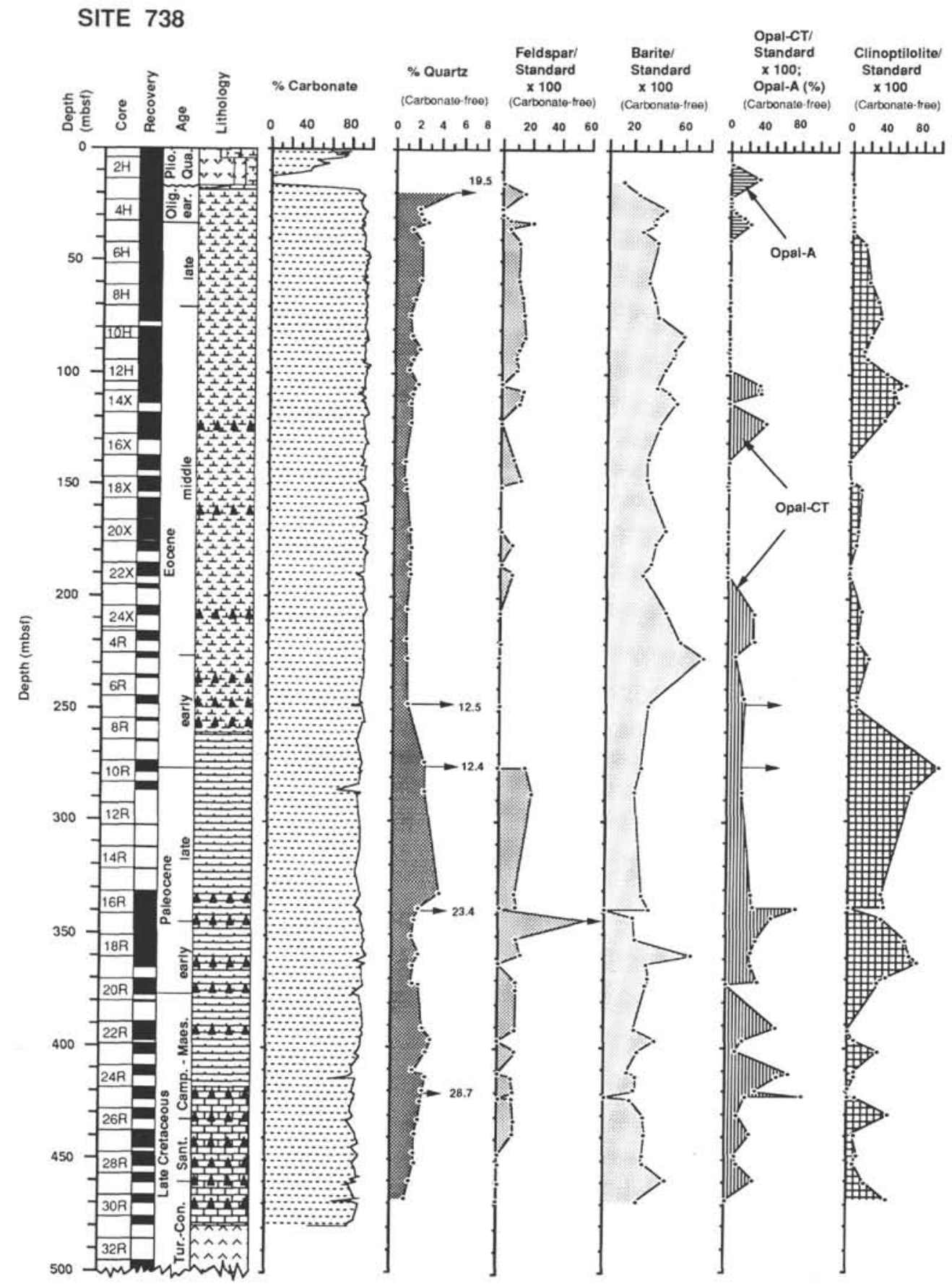

Figure 5. Lithology, age, carbonate content, and results from XRD investigations at Site 738. The semiquantitative patterns of the mineralogical data were calculated on a carbonate-free basis. Opal-A and quartz contents were calculated using calibration curves. Opal-CT is given by the ratio of the opal-CT d(101) peak to the (012) corundum peak $\times 100$. Barite was calculated by the ratio of $I_{(121) \text { barite }}$ to $I_{(012) \text { corundum }} \times 100$. The clinoptilolite pattern is based on the ratio of $I_{(020) \text { clinoptilolite }}$ to $I_{(012) \text { corundum }} \times 100$.

occur in the Oligocene, middle Miocene, and Pliocene. The highest quartz content $(16.4 \%)$ was recorded in Sample 119$744 \mathrm{~A}-16 \mathrm{H}-7,47-49 \mathrm{~cm}$, in lower Oligocene sediments.

The variation of feldspar content in the sediments at Sites 744 and 738 is similar to the quartz pattern. With the exception of the Paleocene, the sediments older than early Oligocene show average intensity ratios $\left(\mathrm{I}_{\text {feldspar }} / \mathrm{I}_{\text {corundum }}\right)$ of about 1000 (Site 738 ; Fig. 5). In the younger sediments at Site 744 , the feldspar inten- sities increase slightly. Maxima with values of up to 8000 were observed in the middle Miocene and Pliocene, and minima within the upper Miocene (Fig. 4).

Barite was identified in all samples at Sites 738 and 744. The relative downhole variation is shown by the $\mathrm{I}_{(121) \text { barite }} / \mathrm{I}_{(012) \text { corundum }}$ ratio (Figs. 4 and 5). Average values of about 3000 are recorded from the Upper Cretaceous to the Paleocene at Site 738 (Fig. 5). Within the lower and middle Eocene, barite concentrations 
reach values between 5000 and 6000 (Fig. 5) and are 3000-4000 within the upper Eocene to middle Miocene, with interruptions within the lower Oligocene (Figs. 4 and 5). The lowest values are found in the late Miocene record (below 500; Fig. 4) and within the post-Miocene sediments (1000-2000; Fig. 4).

Opal-A was not detected by XRD analyses in sediments older than late Eocene (Fig. 5). The small amounts of biogenic opal, less than $20 \%$ on a carbonate-free basis, in the upper Eocene sediments at Site 744 were not recorded at Site 738. Opal-A contents reach an early maximum of $60 \%$ in Cores $119-744 \mathrm{~A}-15 \mathrm{H}$ and $119-744 \mathrm{~A}-16 \mathrm{H}$ within the lower Oligocene. This maximum is also documented by higher contents of dissolved silica in the pore water (Cranston, this volume). Between 50 and $120 \mathrm{mbsf}$ (upper Oligocene to middle Miocene; Fig. 4) opal contents remain low $(0 \%-30 \%)$ and shift to high amounts $(>90 \%)$ within the upper Miocene. In the post-Miocene section, the sediments are still biogenic silica-bearing, and with the exception a value of approximately $20 \%$ in Sample $119-744 \mathrm{~A}-3 \mathrm{H}-1,49-51 \mathrm{~cm}$, opal contents reach about $80 \%$.

At Site 738, opal-CT reflections were documented below 100 mbsf, and fluctuating concentrations in the semiquantitative distribution pattern are shown in Figure 5. The highest values are reached within measurements of four chert nodules, which also show high quartz contents (Fig. 5). Clinoptilolite was found at Site 738 in Cretaceous to upper Eocene sediments (40-480 mbsf; Fig. 5) and shows maximum intensity ratios $\left(\mathrm{I}_{\text {clinoptilolite }} / \mathrm{I}_{\text {corundum }}\right)$ of 300-1000 (Fig. 5) between 270 and 370 mbsf (Paleocene to lower Eocene) and between 100 and 120 mbsf (within the middle Eocene).

\section{DISCUSSION}

The detailed mineral composition and semiquantitative estimates of some mineral components obtained by XRD analyses should provide additional information about the evolution of the depositional environment and sedimentary processes. Because calcareous skeletons, such as foraminifers and calcareous nannofossils, were usually found, with the exception of the upper Miocene to lower Pliocene diatom ooze, the sediments were deposited in a well-oxygenated environment above the calcite compensation depth, which lies today at $5200 \mathrm{~m}$ below sea level (Van Andel et al., 1975). Biogenic silica (opal-A) and most of the biogenic carbonate are of pelagic origin.

\section{Quartz and Feldspar}

The sharp and short-lived quartz peak in the lower Oligocene sediments at Site 744 correlates with a weak maximum of feldspar (Fig. 4), enhanced concentrations of nonbiogenic matter, and a maximum in the gravel and terrigenous sand content ( $>63 \mu \mathrm{m}$ ) of the sediments (Ehrmann, this volume). It further coincides with a minimum in the carbonate concentrations and the onset of opal-A accumulation. This event is interpreted as the initial phase of intense East Antarctic glaciation, which resulted in an influx of large amounts of ice-rafted debris and dissolution of carbonate, probably due to the generation of cold and aggressive bottom waters (Ehrmann, this volume).

From the early Oligocene to Holocene time, ice rafting has influenced sedimentation on the southern Kerguelen Plateau. The ice-rafted gravel and sand component on the southern Kerguelen Plateau is composed mainly of gneissic and, in minor amounts, of granitic material derived from the East Antarctic continent (Ehrmann, this volume). A strong correlation between quartz and feldspar concentrations, therefore, can be expected. Maxima in the quartz and feldspar concentrations at Site 744 occur in the upper lower Oligocene to lower Miocene, middle Miocene, and Pliocene (Fig. 4). They correlate with maxima in the grain-size distribution of terrigenous sand and silt (Ehrmann, this volume) and therefore may reflect phases of enhanced sediment input by ice rafting rather than pure dilution effects by enhanced influx of biogenic opal.

In contrast, no clear correlation between quartz and feldspar can be observed in sediments older than early Oligocene, and their concentrations in the carbonate-free sediment fraction are generally lower than in younger sediments (Fig. 5). An input by ice rafting plays no or only a very minor role down to middle Eocene sediments and can be excluded in the remaining sequence (Barron, Larsen, et al., 1989; Ehrmann, this volume). Instead, at least some of the quartz in the deeper part of Site 738 is of authigenic origin. Authigenic quartz becomes most obvious in the chert nodules occurring at Site 738 between 120 and 480 mbsf (Fig. 5). The enhanced quartz concentrations below 250 mbsf may be due in part to sand- and silt-sized chert fragments, which were generated during rotary drilling and smeared along the core liner during coring and along the cut surface during splitting of the cores (Ehrmann, this volume). However, the presence of opal-CT at this level is an indicator for the diagenetic formation of siliceous minerals and favors an authigenic quartz component.

At Site 737 on the northern Kerguelen Plateau, the background level of feldspar concentrations is about twice as high as on the southern plateau (Fig. 3). Quartz, in contrast, generally occurs in much lower minor concentrations than at Sites 738 and 744. A different source or different transport mechanisms could be responsible for this. Ice rafting from Antarctica should play only a minor role in this distal setting. The proximity to the volcanic rocks of Kerguelen Island implies an input of volcanogenic material and can explain the enhanced feldspar and reduced quartz background concentrations. Maximum feldspar concentrations occur at 240-330 mbsf (Fig. 3), in middle and lowermost upper Miocene sediments, which are characterized by a high amount of volcanic rock fragments (Barron, Larsen, et al., 1989) and volcanic glass. The co-occurrence of sand-sized quartz grains, however, also could imply an ice-rafted origin for this material. For the quartz maximum at 550-710 mbsf, an assumed authigenic origin of the quartz is supported by the fact that the sediment is highly altered by diagenesis; most of the microfossils are silicified, and some chert nodules occur from 697 mbsf downhole (Barron, Larsen, et al., 1989). However, the occurrence of some sand-sized quartz grains makes this origin questionable. The lack of a related feldspar maximum contradicts the idea of an ice-rafted origin.

\section{Barite}

Barite, most common mineral of barium, is widespread in deep-sea sediments (Arrhenius and Bonatti, 1965; Church, 1979; Schmitz, 1987). The source of barium in deep-sea sediments is still under discussion. Barite is associated with hydrothermal activity (Boström et al., 1973; Church, 1979) and also with higher biological productivity in equatorial regions (e.g., Schmitz, 1987). The observations of Bishop (1988) support the hypothesis that barite precipitation occurs partly within the water column in microenvironments that are enriched in sulfate from decaying organic matter, such as fecal pellets and diatom frustules. This investigation may partly explain the commonly reported correlation of biogenic silica and barite in deep-sea sediments (Schmitz, 1987; Bishop, 1988).

The barium cycle in the ocean, however, is even more complex (e.g., barite can be dissolved as well as precipitated during diagenesis; Bishop, 1988). Barite dissolution was reported from sediments rich in organic carbon in the Gulf of California by Brumsack (1989). There, the marked increase in Ba concentrations in the pore water below the sulfate reduction zone indicates barite dissolution. However, this barite dissolution seems to occur in very low sulfate pore-water concentrations. 
At Site 737, sulfate concentration in the interstitial waters gradually decreases from $27 \mathrm{mmol} / \mathrm{L}$ at the top of the section to $15 \mathrm{mmol} / \mathrm{L}$ at the base. At Site 738, interstitial water analyses reveal sulfate concentrations between 23 and $26 \mathrm{mmol} / \mathrm{L}$ (Barron, Larsen, et al., 1989). The sulfate concentrations of the interstitial waters throughout the sediments at Site 744 are essentially the same as in seawater (Barron, Larsen, et al., 1989). The amount of reactive organic matter incorporated into the sediments was sufficient to produce anaerobic conditions and a small sulfate reduction that is taking place over a large depth range, but is too small to exhaust the available sulfate supply. Therefore, sulfate concentrations in the sediments studied here should be high enough throughout to prevent the dissolution of barite.

Barite was not found on the northern Kerguelen Plateau at Site 737, however, and seems to be restricted to the southern area, where it was found in higher amounts at both Sites 738 and 744 (Figs. 5 and 6). Because we may exclude barite dissolution at Site 737, as discussed previously, we have to explain the origin of barite on the southern Kerguelen Plateau in another way. At Site 744, the records of barite and biogenic opal are anticorrelated (Fig. 4), which argues against a biogenic input of barite, as is well known from the Central Indian Ocean (Schmitz, 1987). Other explanations include either diagenetic precipitation or a terrigenous source close to the Antarctic continent, which reached only the southern Kerguelen Plateau. On land, the principal sources for barite are hydrothermal veins, cavity fillings, and concretions in sediments. Because detailed electron microscopic examinations were not performed on the barite fraction, we were unable to distinguish between terrigenous barite and diagenetic barite.

\section{Biogenic Opal}

Below Core 119-737B-9R we cannot estimate the opal-A contents at Site 737 because higher amounts of volcanic glass are present. The occurrence of volcanic glass is well documented by a distinct change in morphology and the maximum height of the silica bulge. In the uppermost 290 mbsf the maximum of the bulge lies between 4.0 and $4.04 \AA$. Within the sediment section from 302 to 371 mbsf a reflection bulge formed at about 3.6 to $3.7 \AA$ is also characterized by a much lower intensity. The abrupt change in bulge type from one sample to the other correlates with a change in the sediment from high amounts of opal-A above to high amounts of volcanic glass below. This interpretation cannot be concluded from the position of the silica bulge alone, because van Bennekom et al. (1988) have described reflection bulges of opal-A that shifted from 4.0 to $3.7 \AA$ as a result of the incorporation of aluminum into the opaline structure. But the intensity values of the silica bulge in relationship to the other reflections observed in the samples between 302 and $371 \mathrm{mbsf}$ indicate the nature of volcanic glass, which is also in accordance with the smear slide observations of Barron, Larsen, et al. (1989).

Despite these difficulties in opal-A determination, two major steps in biogenic silica increase are best documented at Site 744. A short but distinct interval of high biogenic silica well defined in the lower Oligocene at Site 744 (Fig. 4) is less developed at Site 738 (Fig. 5), probably because of diagenetic alteration (e.g., clinoptilolite formation). The increase of biogenic silica occurred just after the initial phase of intense East Antarctic glaciation (Ehrmann, this volume). This distinct cooling event is recorded at Site 744 by different parameters, such as a decrease in carbonate content (Ehrmann, this volume) and a sharp increase of quartz content (Fig. 4), as discussed previously. In response to this climatic change during the reorganization of antarctic oceanography, the high productivity of opaline phytoplankton resulted in a higher opal-A accumulation.

A much stronger late Miocene shift to higher opal contents is recorded in the sequences on both the northern (Fig. 3) and southern (Fig. 4) Kerguelen Plateau. This increase also marks a major change in the paleoceanographic pattern during the $\mathrm{Ce}$ nozoic. High opal-accumulation rates are well recorded at Site 737 (Fig. 3) near the Polar Frontal Zone, which today is the dominant oceanographic feature responsible for high silica sedimentation in the Southern Ocean.

\section{Authigenic Silicate Formation}

\section{Clinoptilolite}

Clinoptilolite is a K-rich zeolite of the heulandite family, and is commonly reported, in addition to phillipsite (Kastner and Stonecipher, 1978), in deep-sea sediments (McCoy et al., 1977; Kastner and Stonecipher, 1978; Riech and von Rad, 1979; Thein and von Rad 1987; Bohrmann et al., 1989). Such zeolites are generally of diagenetic origin, although a common diagenetic evolution for zeolites is not generally accepted. Based on the distribution pattern of phillipsite and clinoptilolite through time, Kastner and Stonecipher (1978) assumed that phillipsite in the younger sediments of the Pacific Ocean is the precursor of the clinoptilolite found in older sediments. There are numerous observations of the relationship of clinoptilolite formation and biogenic silica diagenesis in the Atlantic Ocean (Berger and von Rad, 1972; Riech and von Rad, 1979; Fenner, 1981; Thein and von Rad, 1987; Bohrmann et al., 1989).

Clinoptilolite precipitates from pore water in the presence of alkalines and earth alkalines if sufficient $\mathrm{Al}$ is combined with a high level of dissolved silica. Clinoptilolite precipitation occurs at Site 738 in sediments older than Oligocene and at Site 737 in the Oligocene and Eocene, which is in close accordance with other occurrences of clinoptilolite in deep-sea sediments (Kastner and Stonecipher, 1978).

Below 372 mbsf at Site 737, there is a sharp decrease in interstitial silica concentrations from more than $1000 \mu \mathrm{mol} / \mathrm{L}$ in the overlying sediments to values of about $300 \mu \mathrm{mol} / \mathrm{L}$ (Barron, Larsen, et al., 1989), which corresponds well with the beginning of the downhole occurrence of clinoptilolite (Fig. 3). The concentrations of dissolved silica seem to be depleted by clinoptilolite formation below this depth at Site 737. Similar correlations of silica concentrations in interstitial waters and clinoptilolite content are documented at Site 738 (Fig. 5), although they are less obvious as a result of the generally high carbonate concentrations at Site 738.

According to Stonecipher (1978), clinoptilolite formation should be enhanced in carbonate-rich sediments. In contrast, our results show that clinoptilolite contents are distinctly higher in the sediments at Site 737 (Fig. 3) than at Site 738 (Fig. 5), where carbonate contents are clearly higher. Beside clinoptilolite, opal-CT was precipitated from pore water as a further silica phase in the sediments at Site 737. This precipitation, with the exception of two samples (Fig. 5), was not observed at Site 738. Opal-CT precipitation in sediments clearly requires elevated $\mathrm{Si} / \mathrm{Al}$ ratios in interstitial water composition (Williams and Crerar, 1985). Thus, an opal-CT precipitation simultaneously leads to lower $\mathrm{Si} / \mathrm{Al}$, which could favor clinoptilolite formation after opal-CT precipitation at Site 738. We assume that the increased availability of $\mathrm{Al}, \mathrm{K}$, and $\mathrm{Ca}$ to the pore water at Site 737 caused extensive clinoptilolite growth. This abundance of $\mathrm{Al}$, earth alkalines, and alkalines in the interstitial water could be due to the dissolution of volcanic components. Volcanogenic detritus is more abundant at this site from the northern Kerguelen Plateau, as documented by the higher feldspar contents (Fig. 5).

\section{Opal-CT}

Opal-CT was found in higher amounts only at Site 738, and maximum values are documented in cherts, which clearly are favored sites for silica precipitation. Opal-CT is well established as an intermediate silica phase within the maturation sequence 
from opal-A to quartz (Williams and Crerar, 1985). The transformation of opal-A to opal-CT and then to quartz has been recognized in numerous sediment sections of the Atlantic Ocean (Riech and von Rad, 1979; Thein and von Rad, 1987; Bohrmann and Stein, 1989), the Indian Ocean (Hempel and Bohrmann, in press), and the Pacific Ocean (Keene, 1975; Hein et al., 1978), as well as in onshore sections (Iijima and Tada, 1981; Tada and Iijima, 1983; Murata and Randall, 1975; Pisciotto, 1981). Experimental investigations also support this transformation sequence (Mizutani, 1977; Kastner et al., 1977). Beside host rock lithology and interstitial water chemistry, time and temperature are the most important factors controlling the transformation of silica phases (Murata and Randall, 1975; Hein et al., 1978; Tada, in press). The transformation of silica phases occurs at lower temperatures in older sediments, whereas less time is required for transformation at higher temperatures (Hein et al., 1978). From the Southern Ocean Bohrmann et al. (1990) reported opal-CT-cemented rocks of young age and low burial rate where higher temperatures were not observed.

Opal-CT formation at Site 738 is in accordance with the generally accepted concepts of opal-CT as a maturation process (Williams and Crerar, 1985). This is further supported by the general downhole decrease of opal-CT d(101) spacing from 4.10 to about $4.05 \AA$ (Fig. 6). Although some deviations occur, probably due to different host rock lithologies (Isaacs, 1982) and different generations in diagenetic evolution (Iijima and Tada, 1981), the general trend to lower values is quite obvious. This trend shows an increased ordering of opal-CT during diagenesis, which is also well supported by the hydrothermal experiments conducted by Mizutani (1977).

Because the formation of opal-CT is possible only when considerable amounts of biogenic opal have been deposited, we can assume that higher amounts of biogenic silica skeletons must have been deposited during most of the interval between the Late Cretaceous and Eocene. Because dissolved silica may migrate with pore water vertically and opal-CT precipitation occurs preferentially at favored sites, the productivity of biogenic opal cannot be deduced to correspond to opal-CT precipitation.

\section{ACKNOWLEDGMENTS}

We appreciate the help in sampling by the shipboard scientific party and ODP technical staff aboard JOIDES Resolution. Financial support was provided by the "Deutsche Forschungsgemeinschaft" (Grant No. Fu 119/15). Anke Hienen, Rita Fröhlking, Imke Engelbrecht, and Helga Rhodes are appreciated for their technical assistance. This is Contribution No. 323 of the Alfred Wegener Institute for Polar and Marine Research.

\section{REFERENCES}

Arrhenius, G., and Bonatti, E., 1965. Neptunism and vulcanism in the ocean. In Sears, M. (Ed.), Progress in Oceanography: London (Pergamon Press), 3:7-22.

Barron, J., Larsen, B., et al., 1989. Proc. ODP, Init. Repts., 119: College Station, TX (Ocean Drilling Program).

Berger, W. H., and von Rad, U., 1972. Cretaceous and Cenozoic sediments from the Atlantic Ocean. In Hayes, D. E., Pimm, A. C., et al., Init. Repts. DSDP, 14: Washington (U.S. Govt. Printing Office), 787-954.

Bishop, J.K.B., 1988. The barite-opal organic carbon association in oceanic particulate matter. Nature, 332:341-343.

Bohrmann, G., Kuhn, G., Abelmann, A., Gersonde, R., and Fütterer, D., 1990. A young porcellanite occurrence from the Southwest Indian Ridge. Mar. Geol., 92:155-163.

Bohrmann, G., and Stein, R., 1989. Biogenic silica at ODP Site 647 in the southern Labrador Sea: occurrence, diagenesis, and paleoceanographic implications. In Srivastava, S. P., Arthur, M., Clement, B., et al., Proc. ODP, Sci. Results, 105: College Station, TX (Ocean Drilling Program), 155-170.
Bohrmann, G., Stein, R., and Faugères, J.-C., (1989). Authigenic zeolites and their relation to silica diagenesis in ODP Site 661 sediments (Leg 108, eastern equatorial Atlantic). Geol. Rundsch., 78:779-792.

Boles, J. R., 1972. Composition, optical properties, cell dimension, and thermal stability of some heulandite group zeolites. Am. Mineral., 57:1463-1493.

Boström, K., Joensuu, D., Moore, C., Boström, B., Dalziel, M., and Horowitz, A., 1973. Geochemistry of barium in pelagic sediments. Lithos, 6:159-174.

Brumsack, H. J., 1989. Geochemistry of recent TOC-rich sediments from the Gulf of California and the Black Sea. Geol. Rundsch., 78: 851-882.

Church, T. M., 1979. Marine barite. In Burns, R. G. (Ed.), Reviews in Mineralogy (vol. 6): Mineral Soc. Am., 175-209.

Eisma, D., and Van der Gaast, S. J., 1971. Determination of opal in marine sediments by X-ray diffraction. Neth. J. Sea Res., 5:382-389.

Fenner, J., 1981. Diatoms in the Eocene and Oligocene sediments off NW Africa, their stratigraphic and paleogeographic occurrences [Ph.D. dissert.]. Univ. Kiel, FRG.

Hein, J. R., Scholl, D. W., Barron, J. A., Jones, M. G., and Miller, J., 1978. Diagenesis of late Cenozoic diatomaceous deposits and formation of the bottom simulating reflector in the southern Bering Sea. Sedimentology, 25:155-181.

Hempel, P., and Bohrmann, G., in press. Carbonate-free sediment components and aspects of silica diagenesis at Sites 707, 709, and 711 (Leg 115, western Indian Ocean). In Backman, J., Duncan, R. A., et al., Proc. ODP, Sci. Results, 115: College Station, TX (Ocean Drilling Program).

Iijima, A., and Tada, R., 1981. Silica diagenesis of Neogene diatomaceous and volcaniclastic sediments in northern Japan. Sedimentology, 28:185-200.

Isaacs, C. M., 1982. Influence of rock compositions on kinetics of silica phase changes in the Monterey Formation, Santa Barbara area, California. Geology, 10:304-308.

Kastner, M., Keene, J. B., and Gieskes, J. M., 1977. Diagenesis of siliceous oozes. I. Chemical controls on the rate of opal-A to opal-CT transformation-an experimental study. Geochim. Cosmochim. Acta, 41:1041-1059.

Kastner, M., and Stonecipher, S.A., 1978. Zeolites in pelagic sediments of the Atlantic, Pacific, and Indian oceans. In Sand, L. B., and Mumpton, F. A. (Eds.), Natural Zeolite: Occurrence, Properties, Use: New York (Pergamon Press), 199-218.

Keene, J. B., 1975. Cherts and porcellanites from the North Pacific, DSDP Leg 32. In Larsen, R. L., Moberly, R., et al., Init. Repts. $D S D P$, 32: Washington (U.S. Govt. Printing Office), 429-507.

McCoy, F., Zimmerman, H., and Krinsley, D., 1977. Zeolites in South Atlantic deep-sea sediments. In Supko, P. R., Perch-Nielsen, K., et al., Init. Repts. DSDP, 39: Washington (U.S. Govt. Printing Office), 423-443.

Mizutani, S., 1977. Progressive ordering of cristobalitic silica in the early stage of diagenesis. Contrib. Mineral. Petrol., 61:129-140.

Murata, K. J., and Randall, R. G., 1975. Silica mineralogy and structure of the Monterey Shale, Temblor Range, California. J. Res. U.S. Geol Survey, 3:567-572.

Pisciotto, K. A., 1981. Distribution, thermal histories, isotopic compositions, and reflection characteristics of siliceous rocks recovered by the Deep Sea Drilling Project. In Warme, J. E., Douglas, R. G., and Winterer, E. L. (Eds.), The Deep Sea Drilling Project: A Decade of Progress. SEPM Spec. Publ., 32:129-148.

Riech, V., and von Rad, U., 1979. Silica diagenesis in the Atlantic Ocean: diagenetic potential and transformations. In Talwani, M., Hay, W., and Ryan, W.B.F. (Eds.), Deep Drilling Results in the Atlantic Ocean: Continental Margins and Paleoenvironment: Am. Geophys. Union, Maurice Ewing Ser., 3:315-340.

Schmitz, B., 1987. Barium, equatorial high productivity, and the northward wandering of the Indian continent. Paleoceanography, 2:6377.

Stonecipher, S. A., 1978. Geochemistry and deep-sea phillipsite, clinoptilolite, and host sediments. In Sand, L. B., and Mumpton, F. A. (Eds.), Natural Zeolite: Occurrence, Properties, Use: New York (Pergamon Press), 221-234.

Tada, R., in press. Compaction and cementation in siliceous rocks and their possible effects on bedding enhancement. In Cycles and Events in Stratigraphy: (Springer). 
Tada, R., and lijima, A., 1983. Petrology and diagenetic changes of Neogene siliceous rocks in northern Japan. J. Sediment. Petrol., 53: 911-930.

Thein, J., and von Rad, U., 1987. Silica diagenesis in continental rise and slope sediments off eastern North America (Sites 603 and 605, Leg 93; Sites 612 and 614, Leg 95). In Poag, C. W., Watts, A. B., et al., Init. Repts. DSDP, 95: Washington (U.S. Govt. Printing Office), 501-525.

Van Andel, T. H., 1975. Mesozoic/Cenozoic calcite compensation depth and the global distribution of calcareous sediments. Earth Planet. Sci. Lett., 26:187-194.

van Bennekom, A. J., Jansen, J.H.F., van der Gaast, S. J., van Iperen, Y. M., and Pieters, J., 1988. Aluminium-rich opal: an intermediate in the preservation of biogenic silica in the Zaire (Congo) deep-sea fan. Deep-Sea Res., Part A, 36:173-190.

Whitworth, T., III, 1988. The Antarctic Circumpolar Current. Oceamus, $31: 53-58$.

Williams, L. A., and Crerar, D. A., 1985. Silica diagenesis, II. General mechanisms. J. Sediment. Petrol., 55:313-321.

Date of initial receipt: 6 February 1990

Date of acceptance: 22 June 1990

Ms 119B-122

\section{Site 738}

Opal-CT d(101) spacing (A)

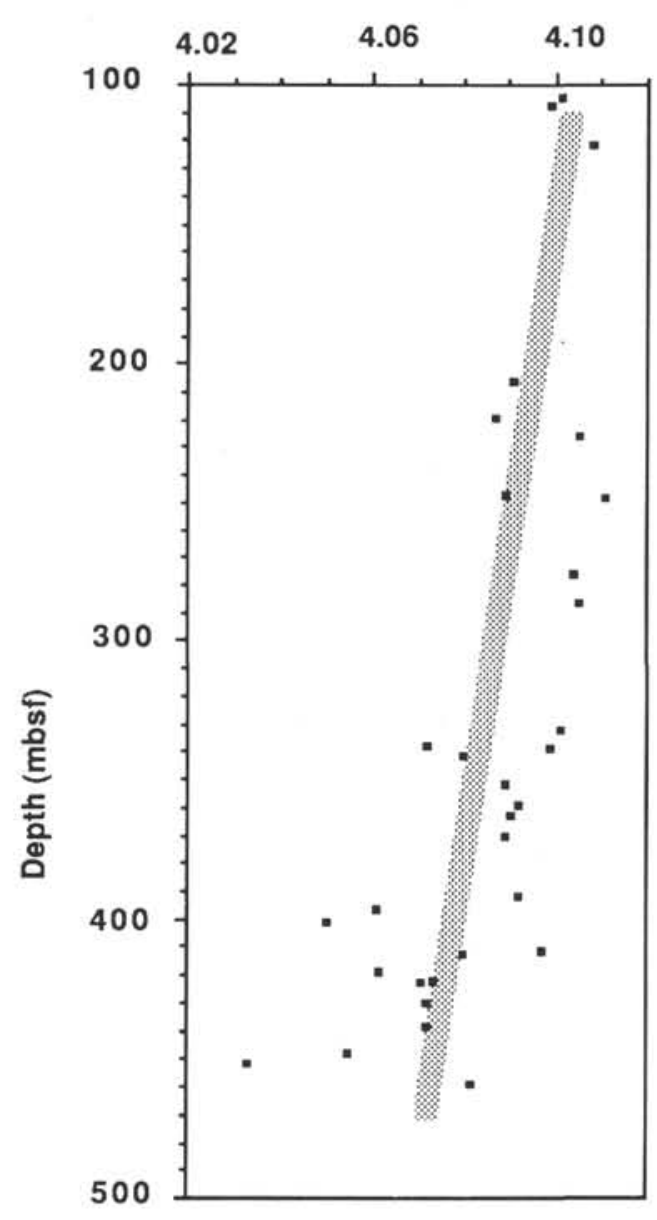

Figure 6. Variation of opal-CT d(101) spacing with depth in sediments from ODP Site 738 . 
Appendix Table 1. Results from X-ray-diffraction analyses (based on the carbonate-free sample) of sediments from Site 737 .

\begin{tabular}{|c|c|c|c|c|c|c|c|}
\hline $\begin{array}{l}\text { Core, section, } \\
\text { interval }(\mathrm{cm})\end{array}$ & $\begin{array}{l}\text { Depth } \\
\text { (mbsf) }\end{array}$ & $\begin{array}{c}\text { Carbonate } \\
(\%)\end{array}$ & $\begin{array}{c}\text { Quartz } \\
(\%)\end{array}$ & $\begin{array}{l}\text { Feldspar/ } \\
\text { standard } \\
(\times 100)\end{array}$ & $\begin{array}{l}\text { Clinoptilolite/ } \\
\text { standard } \\
(\times 100)\end{array}$ & $\begin{array}{l}\text { Opal-A } \\
(\%)\end{array}$ & Remarks \\
\hline \multicolumn{8}{|l|}{$119-737 \mathrm{~A}-$} \\
\hline $1 \mathrm{H}-2,48-50$ & 1.98 & 0.16 & 1.90 & 35.1 & 0.0 & 0 & \\
\hline $2 \mathrm{H}-7,36-40$ & 14.09 & 2.14 & 0.10 & 23.9 & 0.0 & 71 & \\
\hline $3 \mathrm{H}-7,48-52$ & 23.52 & 1.13 & 0.97 & 26.4 & 0.0 & 83 & \\
\hline $4 \mathrm{H}-7,48-52$ & 32.93 & 0.09 & 0.20 & 25.7 & 0.0 & 66 & \\
\hline SH-2, $48-50$ & 35.48 & 2.50 & 0.10 & 40.1 & 0.0 & 55 & \\
\hline $6 \mathrm{H}-2,56-60$ & 45.06 & 1.95 & 0.44 & 29.6 & 0.0 & 48 & \\
\hline $6 \mathrm{H}-4,60-64$ & 48.10 & 0.29 & 0.10 & 27.0 & 0.0 & 58 & \\
\hline $7 \mathrm{H}-2,48-50$ & 54.48 & 0.03 & 0.32 & 31.0 & 0.0 & 45 & \\
\hline $9 \mathrm{H}-2,48-50$ & 73.48 & 0.59 & 0.10 & 35.2 & 0.0 & 45 & \\
\hline $9 \mathrm{H}-7,48-52$ & 80.62 & 6.63 & 0.09 & 24.0 & 0.0 & 70 & \\
\hline $10 \mathrm{H}-2,48-52$ & 82.98 & 2.36 & 4.35 & 43.1 & 0.0 & 24 & \\
\hline $11 \mathrm{H}-2,48-50$ & 92.48 & 0.34 & 0.07 & 15.6 & 0.0 & 85 & \\
\hline $11 \mathrm{H}-7,12-16$ & 99.44 & 0.26 & 0.05 & 17.1 & 0.0 & 67 & \\
\hline $12 \mathrm{H}-7,10-14$ & 108.67 & 0.47 & 0.10 & 15.8 & 0.0 & 73 & \\
\hline $13 \mathrm{H}-5,48-50$ & 115.98 & 0.17 & 0.05 & 15.5 & 0.0 & 80 & \\
\hline $15 \mathrm{H}-5,24-28$ & 134.74 & 0.89 & 0.23 & 26.2 & 0.0 & 56 & \\
\hline $16 \mathrm{H}-6,78-82$ & 146.04 & 0.70 & 0.05 & 14.5 & 0.0 & 71 & \\
\hline $17 \mathrm{H}-3,48-52$ & 150.91 & 0.15 & 0.08 & 36.7 & 0.0 & 60 & \\
\hline $18 \mathrm{H}-2,48-52$ & 158.98 & 0.39 & 0.10 & 10.4 & 0.0 & 92 & \\
\hline $18 \mathrm{H}-7,30-34$ & 166.12 & 0.24 & 0.03 & 15.4 & 0.0 & 81 & \\
\hline $19 \mathrm{X}-1,48-50$ & 166.98 & 10.01 & 0.02 & 16.1 & 0.0 & 84 & \\
\hline $23 \mathrm{X}-1,48-52$ & 205.78 & 0.00 & 0.08 & 17.5 & 0.0 & 50 & \\
\hline $25 \mathrm{X}-3,10-14$ & 227.80 & & 0.53 & 25.1 & 0.0 & 60 & \\
\hline $26 X-2,4-8$ & 235.94 & 0.13 & 0.10 & 10.5 & 0.0 & 51 & \\
\hline $27 X-3,46-50$ & 247.56 & 8.01 & 2.32 & 695.8 & 0.0 & & Volcanic glass? \\
\hline $28 \mathrm{X}-1,100-102$ & 254.80 & 16.76 & 0.56 & 49.0 & 0.0 & 45 & \\
\hline \multicolumn{8}{|l|}{ 119-737B- } \\
\hline $6 \mathrm{R}-1,126-130$ & 264.46 & 77.67 & 0.30 & 15.4 & 0.0 & 34 & \\
\hline $6 \mathrm{R}-5,10-12$ & 269.30 & 78.34 & 0.72 & 27.7 & 0.0 & 57 & \\
\hline $7 \mathrm{R}-1,48-52$ & 273.38 & 96.71 & 1.17 & 45.6 & 0.0 & 22 & \\
\hline $8 \mathrm{R}-1,58-62$ & 283.08 & 79.77 & 0.35 & 33.8 & 0.0 & 27 & \\
\hline $9 \mathrm{R}-1,38-42$ & 292.58 & 62.60 & 0.05 & 16.9 & 0.0 & 80 & \\
\hline $10 \mathrm{R}-1,38-42$ & 302.18 & 44.26 & 1.00 & 52.0 & 0.0 & & Volcanic glass \\
\hline $11 \mathrm{R}-2,48-50$ & 313.48 & 83.23 & 3.07 & 44.2 & 83.5 & & Volcanic glass \\
\hline $12 \mathrm{R}-3,58-60$ & 324.68 & 31.89 & 0.09 & 164.8 & 0.0 & & Volcanic glass \\
\hline $13 \mathrm{R}-1,48-50$ & 331.28 & 19.32 & 0.52 & 102.6 & 0.0 & & Volcanic glass \\
\hline $14 \mathrm{R}-4,56-58$ & 345.46 & 39.77 & 0.05 & 15.1 & 0.0 & & Volcanic glass \\
\hline $15 \mathrm{R}-4,50-52$ & 355.10 & 8.16 & 0.06 & 14.8 & 0.0 & & Volcanic glass \\
\hline $16 \mathrm{R}-3,50-52$ & 363.30 & 25.76 & 0.04 & 11.7 & 0.0 & & Volcanic glass \\
\hline $17 \mathrm{R}-2,50-52$ & 371.40 & 26.00 & 0.03 & 13.6 & 0.0 & & Volcanic glass \\
\hline $18 \mathrm{R}-1,48-50$ & 379.58 & 20.87 & 0.27 & 25.1 & 54.1 & & \\
\hline $19 \mathrm{R}-2,48-50$ & 390.68 & 20.88 & 0.01 & 11.3 & 82.2 & & \\
\hline $20 \mathrm{R}-4,52-54$ & 403.42 & 10.21 & 0.01 & 12.3 & 132.0 & & \\
\hline $21 \mathrm{R}-2,50-52$ & 410.10 & 11.36 & 0.02 & 13.6 & 215.1 & & \\
\hline $22 \mathrm{R}-7,48-50$ & 427.09 & 21.88 & 0.01 & 30.6 & 130.8 & & \\
\hline $24 \mathrm{R}-3,49-51$ & 440.49 & 39.74 & 0.01 & 21.7 & 116.6 & & \\
\hline $25 \mathrm{R}-2,44-48$ & 448.64 & 34.18 & 0.35 & 18.6 & 53.2 & & \\
\hline $26 \mathrm{R}-4,50-52$ & 460.40 & 49.42 & 0.02 & 26.7 & 88.7 & & \\
\hline $27 \mathrm{R}-2,70-72$ & 468.20 & 18.75 & 0.03 & 17.9 & 180.8 & & \\
\hline $29 \mathrm{R}-4,60-62$ & 490.40 & 26.65 & 0.00 & 12.1 & 45.6 & & \\
\hline $30 R-4,58-60$ & 500.08 & 43.40 & 0.01 & 7.4 & 17.4 & & \\
\hline $31 \mathrm{R}-4,50-52$ & 509.60 & 54.37 & 0.01 & 18.3 & 41.8 & & \\
\hline $33 \mathrm{R}-1,37-39$ & 524.37 & 57.56 & 0.01 & 7.8 & 100.0 & & \\
\hline $34 \mathrm{R}-1,51-53$ & 534.11 & 24.96 & 0.02 & 19.7 & 7.1 & & \\
\hline $34 \mathrm{R}-5,48-52$ & 540.08 & & 0.02 & 15.1 & 95.5 & & \\
\hline $35 \mathrm{R}-3,48-50$ & 546.78 & 18.41 & 0.01 & 29.6 & 56.8 & & \\
\hline $36 \mathrm{R}-2,134-138$ & 555.74 & 23.37 & 0.81 & 19.8 & 108.9 & & Chert (opal-CT) \\
\hline $37 \mathrm{R}-3,50-52$ & 566.00 & 12.24 & 0.01 & 23.8 & 244.8 & & \\
\hline $38 R-4,44-46$ & 577.14 & 36.60 & 2.59 & 22.5 & 175.7 & & \\
\hline $39 \mathrm{R}-4,56-58$ & 586.81 & 55.47 & 2.76 & 24.6 & 110.9 & & \\
\hline $40 \mathrm{R}-1,77-79$ & 592.27 & 39.34 & 0.83 & 20.8 & 145.4 & & \\
\hline $41 R-4,54-56$ & 606.14 & 35.49 & 2.54 & 24.0 & 92.5 & & \\
\hline $42 R-3,51-53$ & 614.21 & 38.98 & 0.91 & 15.8 & 194.0 & & \\
\hline $44 R-4,49-51$ & 634.99 & 51.99 & 0.98 & 23.0 & 97.3 & & \\
\hline $45 \mathrm{R}-1,15-19$ & 639.75 & 83.87 & 12.46 & 23.0 & 102.3 & & Chert (opal-CT) \\
\hline $46 \mathrm{R}-1,100-102$ & 650.30 & 73.09 & 3.19 & 28.0 & 331.3 & & \\
\hline $47 \mathrm{R}-2,100-102$ & 661.10 & 6.84 & 0.01 & 6.0 & 40.0 & & \\
\hline $48 \mathrm{R}-2,100-102$ & 670.40 & 84.41 & 1.86 & 7.0 & 49.6 & & \\
\hline $49 R-4,95-97$ & 683.05 & 70.54 & 1.42 & 5.9 & 52.7 & & \\
\hline $50 \mathrm{R}-3,52-54$ & 690.02 & 51.69 & 1.39 & 9.0 & 60.0 & & \\
\hline $51 \mathrm{R}-1,50-52$ & 696.70 & 89.43 & 24.96 & 14.4 & 32.6 & & \\
\hline $52 \mathrm{R}-3,50-52$ & 709.40 & 83.80 & 2.21 & 10.4 & 117.2 & & \\
\hline
\end{tabular}


Appendix Table 2. Results from X-ray-diffraction analyses (based on the carbonate-free sample) of sediments from Site 738.

\begin{tabular}{|c|c|c|c|c|c|c|c|c|c|c|}
\hline $\begin{array}{l}\text { Core, section, } \\
\text { interval }(\mathrm{cm})\end{array}$ & $\begin{array}{l}\text { Depth } \\
\text { (mbsf) }\end{array}$ & $\begin{array}{c}\text { Carbonate } \\
(\%)\end{array}$ & $\begin{array}{l}\text { Quartz } \\
(\%)\end{array}$ & $\begin{array}{l}\text { Feldspar/ } \\
\text { standard } \\
(\times 100)\end{array}$ & $\begin{array}{l}\text { Barite/ } \\
\text { standard } \\
(\times 100)\end{array}$ & $\begin{array}{l}\text { Opal-A } \\
(\%)\end{array}$ & $\begin{array}{l}\text { Opal-CT/ } \\
\text { standard } \\
(\times 100)\end{array}$ & $\begin{array}{c}\text { Opal-CT } \\
\text { d(101) } \\
(\AA)\end{array}$ & $\begin{array}{l}\text { Clinoptilolite/ } \\
\text { standard } \\
(\times 100)\end{array}$ & Remarks \\
\hline \multicolumn{11}{|l|}{ 119-738B- } \\
\hline $3 \mathrm{H}-1,125-129$ & 14.75 & 0.0 & 19.5 & 0.0 & 11.8 & 3 & 0.0 & & 0.0 & \\
\hline $3 \mathrm{H}-5,48-52$ & 19.98 & 87.3 & 5.0 & 14.6 & 25.5 & 33 & 0.0 & & 0.0 & \\
\hline $4 \mathrm{H}-3,48-52$ & 26.35 & 92.2 & 2.0 & 0.0 & 45.9 & 0 & 0.0 & & 0.0 & \\
\hline $4 \mathrm{H}-5,78-82$ & 29.52 & 92.7 & 2.2 & 0.0 & 36.7 & 1 & 0.0 & & 0.0 & \\
\hline $4 \mathrm{H}-7,30-34$ & 31.94 & 90.4 & 2.5 & 5.9 & 34.8 & 5 & 0.0 & & 0.0 & \\
\hline $5 \mathrm{H}-1,100-104$ & 33.46 & 89.8 & 2.8 & 22.0 & 37.2 & 13 & 0.0 & & 0.0 & \\
\hline $5 \mathrm{H}-3,48-52$ & 35.85 & 89.2 & 1.5 & 4.5 & 26.7 & 24 & 0.0 & & 0.0 & \\
\hline $5 \mathrm{H}-7,30-34$ & 41.44 & 94.0 & 2.3 & 11.7 & 39.5 & 0 & 0.0 & & 16.4 & \\
\hline $7 \mathrm{H}-5,48-52$ & 57.79 & 90.6 & 2.3 & 10.8 & 31.7 & & 0.0 & & 21.1 & \\
\hline $8 \mathrm{H}-5,48-52$ & 67.29 & 93.4 & 1.7 & 14.0 & 38.4 & & 0.0 & & 31.4 & \\
\hline $9 \mathrm{H}-3,48-52$ & 73.98 & 94.0 & 1.3 & 14.6 & 39.4 & & 0.0 & & 33.6 & \\
\hline $10 \mathrm{H}-3,48-52$ & 83.48 & 95.3 & 1.4 & 16.2 & 61.7 & & 0.0 & & 21.6 & \\
\hline $11 \mathrm{H}-3,48-52$ & 88.48 & & 2.2 & 12.0 & 54.4 & & 0.0 & & 15.7 & \\
\hline $11 \mathrm{H}-5,48-52$ & 91.48 & 93.3 & 1.8 & 10.1 & 52.6 & & 0.0 & & 14.2 & \\
\hline $12 \mathrm{H}-3,48-52$ & 97.98 & 94.2 & 1.2 & 10.9 & 44.9 & & 0.0 & & 38.3 & \\
\hline $13 \mathrm{H}-1,48-52$ & 104.47 & 93.6 & 2.0 & 0.0 & 38.6 & & 34.6 & 4.101 & 60.8 & \\
\hline $13 \mathrm{H}-3,48-52$ & 107.17 & 92.0 & 1.6 & 15.2 & 46.0 & & 36.9 & 4.099 & 47.6 & \\
\hline $14 X-3,48-52$ & 111.68 & 91.2 & 1.5 & 12.6 & 54.2 & & 0.0 & & 53.3 & \\
\hline $15 X-3,48-52$ & 121.28 & 93.1 & 1.4 & 0.0 & 41.7 & & 43.1 & 4.108 & 34.5 & \\
\hline $17 X-1,60-64$ & 137.80 & 91.5 & 1.0 & 9.1 & 31.8 & & 0.0 & & 0.0 & \\
\hline $18 \times-1,48-52$ & 147.28 & 94.5 & 0.9 & 14.4 & 31.5 & & 0.0 & & 0.0 & \\
\hline $18 \times-3,48-52$ & 150.28 & 93.3 & 1.1 & 0.0 & 33.3 & & 0.0 & & 13.4 & \\
\hline $20 X-3,48-52$ & 169.68 & 96.7 & 1.4 & 0.0 & 45.6 & & 0.0 & & 9.6 & \\
\hline $21 X-1,48-52$ & 176.28 & 95.8 & 1.4 & 7.9 & 38.8 & & 0.0 & & 6.8 & \\
\hline $22 \mathrm{X}-1,48-52$ & 185.88 & 94.9 & 1.5 & 0.0 & 34.9 & & 0.0 & & 0.0 & \\
\hline $22 X-3,48-52$ & 188.88 & 94.9 & 1.4 & 8.7 & 29.4 & & 0.0 & & 0.0 & \\
\hline $24 \mathrm{X}-2,48-52$ & 206.58 & 95.3 & 1.1 & 0.0 & 46.8 & & 29.1 & 4.091 & 12.8 & \\
\hline \multicolumn{11}{|l|}{$119-738 \mathrm{C}$ - } \\
\hline $4 \mathrm{R}-3,48-52$ & 219.38 & 93.1 & 1.1 & 0.0 & 57.6 & & 30.1 & 4.087 & 8.7 & \\
\hline $5 \mathrm{R}-1,46-50$ & 226.06 & 94.2 & 1.2 & 0.0 & 77.2 & & 8.8 & 4.105 & 22.4 & \\
\hline $7 \mathrm{R}-2,74-76$ & 247.04 & 93.6 & 1.3 & 0.0 & 34.4 & & 19.8 & 4.089 & 6.7 & Smectites \\
\hline $7 \mathrm{R}-2,90-92$ & 247.20 & & 12.0 & 0.0 & 0.0 & & 97.0 & 4.111 & 0.0 & Chert \\
\hline $10 \mathrm{R}-2,8-10$ & 275.38 & & 12.4 & 0.0 & 0.0 & & 116.8 & 4.104 & 0.0 & Chert \\
\hline $10 \mathrm{R}-2,36-38$ & 275.66 & 92.2 & 2.8 & 18.3 & 28.4 & & 15.7 & 4.103 & 100.0 & \\
\hline $11 \mathrm{R}-3,10-12$ & 286.50 & 92.4 & 2.8 & 21.6 & 23.3 & & 16.9 & 4.105 & 70.9 & \\
\hline $16 \mathrm{R}-1,48-52$ & 332.08 & 92.5 & 4.1 & 10.9 & 28.9 & & 28.3 & 4.101 & 37.7 & \\
\hline $16 \mathrm{R}-5,42-44$ & 338.02 & 91.1 & 2.5 & 13.1 & 35.0 & & 30.0 & 4.072 & 40.6 & \\
\hline $16 \mathrm{R}-5,54-58$ & 338.14 & & 23.2 & 0.0 & 0.0 & & 80.6 & 4.098 & 0.0 & Chert \\
\hline $17 \mathrm{R}-1,58-60$ & 341.86 & 92.8 & 2.0 & 116.0 & 23.4 & & 51.0 & 4.080 & 37.7 & \\
\hline $18 \mathrm{R}-1,70-74$ & 351.60 & 97.1 & 1.7 & 11.5 & 23.6 & & 34.2 & 4.089 & 64.1 & \\
\hline $18 R-6,48-52$ & 358.88 & 99.2 & 2.4 & 14.7 & 68.8 & & 27.2 & 4.092 & 68.8 & \\
\hline $19 R-2,70-74$ & 362.70 & 98.3 & 2.0 & 0.0 & 33.9 & & 28.1 & 4.090 & 79.4 & \\
\hline $20 \mathrm{R}-1,20-24$ & 370.40 & 94.7 & 1.7 & 12.9 & 34.5 & & 36.3 & 4.089 & 32.4 & \\
\hline $20 \mathrm{R}-2,50-54$ & 372.20 & 96.1 & 2.3 & 11.8 & 32.9 & & 0.0 & & 34.4 & \\
\hline $22 \mathrm{R}-2,62-65$ & 391.72 & 94.2 & 2.7 & 12.0 & 23.8 & & 57.4 & 4.092 & 0.0 & \\
\hline $22 \mathrm{R}-5,51-53$ & 396.40 & 94.9 & 3.5 & 0.0 & 41.0 & & 18.1 & 4.061 & 7.6 & \\
\hline $23 R-2,47-49$ & 401.17 & 90.7 & 3.1 & 13.0 & 26.6 & & 11.2 & 4.050 & 33.7 & \\
\hline $24 \mathrm{R}-2,60-62$ & 411.00 & 86.4 & 2.0 & 0.0 & 17.8 & & 73.4 & 4.097 & 6.4 & \\
\hline $24 \mathrm{R}-3,50-52$ & 412.40 & 83.1 & 3.0 & 8.6 & 25.5 & & 59.7 & 4.080 & 9.6 & \\
\hline $25 \mathrm{R}-1,64-66$ & 419.24 & 85.2 & 2.8 & 10.9 & 25.0 & & 31.5 & 4.062 & 0.0 & \\
\hline $25 \mathrm{R}-3,56-60$ & 422.16 & & 28.7 & 0.0 & 0.0 & & 87.2 & 4.074 & 0.0 & Chert \\
\hline $25 \mathrm{R}-3,72-74$ & 422.32 & 88.5 & 2.7 & 10.0 & 21.4 & & 23.0 & 4.071 & 6.5 & \\
\hline $26 \mathrm{R}-2,54-56$ & 430.24 & 87.7 & 2.5 & 10.7 & 31.8 & & 13.5 & 4.072 & 47.2 & \\
\hline $27 \mathrm{R}-1,49-51$ & 438.39 & 89.7 & 2.1 & 10.9 & 33.3 & & 28.6 & 4.072 & 6.3 & \\
\hline $28 \mathrm{R}-1,55-57$ & 448.15 & 92.9 & 2.0 & 0.0 & 30.8 & & 9.5 & 4.055 & 11.5 & \\
\hline $28 \mathrm{R}-3,48-50$ & 451.08 & 86.6 & 2.0 & 0.0 & 30.4 & & 11.7 & 4.033 & 7.0 & \\
\hline $29 \mathrm{R}-2,48-50$ & 459.18 & 84.6 & 1.6 & 0.0 & 47.5 & & 32.9 & 4.082 & 17.6 & \\
\hline $30 \mathrm{R}-2,48-50$ & 468.58 & 84.6 & 1.2 & 0.0 & 24.7 & & 0.0 & & 43.8 & \\
\hline
\end{tabular}


Appendix Table 3. Results from X-ray-diffraction analyses (based on the carbonate-free sample) of sediments from Site 744.

\begin{tabular}{|c|c|c|c|c|c|c|}
\hline $\begin{array}{l}\text { Core, section, } \\
\text { interval }(\mathrm{cm})\end{array}$ & $\begin{array}{l}\text { Depth } \\
\text { (mbsf) }\end{array}$ & $\begin{array}{c}\text { Carbonate } \\
(\%)\end{array}$ & $\begin{array}{c}\text { Quartz } \\
(\%)\end{array}$ & $\begin{array}{c}\text { Feldspar/ } \\
\text { standard } \\
(\times 100)\end{array}$ & $\begin{array}{l}\text { Barite/ } \\
\text { standard } \\
(\times 100)\end{array}$ & $\begin{array}{c}\text { Opal-A } \\
(\%)\end{array}$ \\
\hline \multicolumn{7}{|l|}{$119-744 \mathrm{~A}-$} \\
\hline $1 \mathrm{H}-1,49-51$ & 0.49 & 29.82 & 2.7 & 4.2 & 19.5 & 84 \\
\hline $1 \mathrm{H}-3,49-51$ & 3.49 & 60.96 & 4.0 & 15.6 & 14.4 & 74 \\
\hline $2 \mathrm{H}-1,49-51$ & 4.69 & 62.69 & 2.5 & 9.3 & 7.7 & 87 \\
\hline $2 \mathrm{H}-4,49-51$ & 9.19 & 32.57 & 3.8 & 39.8 & 14.8 & 80 \\
\hline $3 \mathrm{H}-1,49-51$ & 14.19 & 29.01 & 10.8 & 82.0 & 13.8 & 22 \\
\hline $3 \mathrm{H}-4,49-51$ & 18.69 & 3.91 & 5.4 & 16.0 & 16.0 & 60 \\
\hline $4 \mathrm{H}-2,46-50$ & 25.16 & 89.86 & 1.7 & 4.1 & 10.3 & 82 \\
\hline $4 \mathrm{H}-3,40-44$ & 26.60 & 91.01 & 3.3 & 6.0 & 11.2 & 78 \\
\hline $5 \mathrm{H}-2,40-44$ & 34.60 & 81.60 & 2.0 & 2.6 & 2.6 & 79 \\
\hline $5 \mathrm{H}-4,12-15$ & 37.32 & 73.43 & 1.1 & & 3.0 & 94 \\
\hline $6 \mathrm{H}-2,60-64$ & 44.30 & 86.44 & 0.4 & & 4.0 & 95 \\
\hline $6 \mathrm{H}-4,49-51$ & 45.66 & 91.38 & 1.8 & 8.9 & & \\
\hline $7 \mathrm{H}-2,46-50$ & 53.66 & 82.87 & 7.8 & 24.9 & 19.9 & 11 \\
\hline $7 \mathrm{H}-3,46-50$ & 55.16 & 79.73 & 7.4 & 20.8 & 30.1 & 13 \\
\hline $7 \mathrm{H}-4,49-51$ & 59.40 & 77.47 & 9.2 & 10.5 & 34.9 & 15 \\
\hline $8 \mathrm{H}-2,46-50$ & 63.16 & 78.32 & 6.1 & 22.5 & 27.6 & 25 \\
\hline $8 \mathrm{H}-3,46-50$ & 64.66 & 82.24 & 10.6 & 32.1 & 36.7 & 15 \\
\hline $8 \mathrm{H}-4,49-51$ & 66.19 & 84.00 & 5.8 & 25.1 & 49.3 & 10 \\
\hline $9 \mathrm{H}-1,49-51$ & 71.19 & 93.45 & 3.2 & 33.9 & 27.7 & 0 \\
\hline $10 \mathrm{H}-2,46-50$ & 81.60 & 90.15 & 2.8 & 14.6 & 28.6 & 30 \\
\hline $10 \mathrm{H}-7,48-52$ & 89.32 & 90.52 & 5.0 & 17.7 & 35.5 & 13 \\
\hline $11 \mathrm{H}-3,48-52$ & 93.18 & 89.03 & 6.0 & 15.8 & 28.9 & 31 \\
\hline $11 \mathrm{H}-6,48-52$ & 97.68 & 83.18 & 6.8 & 22.6 & 26.8 & 6 \\
\hline $12 \mathrm{H}-3,48-52$ & 102.55 & 89.76 & 6.9 & 19.6 & 27.0 & 26 \\
\hline $12 \mathrm{H}-6,46-50$ & 106.85 & 89.47 & 6.7 & 28.5 & 22.0 & 13 \\
\hline $13 \mathrm{H}-6,46-50$ & 116.58 & 91.19 & 8.4 & 24.7 & 27.0 & 4 \\
\hline $14 \mathrm{H}-6,46-50$ & 126.16 & 88.65 & 8.4 & 15.5 & 24.0 & 22 \\
\hline $15 \mathrm{H}-3,46-50$ & 131.06 & 87.74 & 3.5 & 5.6 & 16.0 & 61 \\
\hline $15 \mathrm{H}-6,46-50$ & 135.43 & 88.96 & 3.4 & 7.3 & 10.0 & 69 \\
\hline $16 \mathrm{H}-2,46-50$ & 139.09 & 87.14 & 4.2 & 4.3 & 22.0 & 60 \\
\hline $16 \mathrm{H}-5,46-50$ & 143.41 & 82.01 & 1.8 & 2.3 & 14.0 & 85 \\
\hline $16 \mathrm{H}-7,47-49$ & 146.31 & 61.26 & 16.4 & 17.5 & 8.0 & 15 \\
\hline $18 \mathrm{H}-1,49-51$ & 148.08 & 91.82 & 2.0 & 12.5 & 30.0 & 0 \\
\hline $19 \mathrm{H}-1,49-51$ & 157.59 & 93.78 & 2.1 & 6.5 & 32.0 & 0 \\
\hline $19 \mathrm{H}-6,46-50$ & 165.06 & 90.78 & 2.0 & 4.6 & 33.0 & 19 \\
\hline $20 \mathrm{H}-1,42-46$ & 167.00 & 88.60 & 2.0 & 5.1 & 35.0 & 8 \\
\hline $20 \mathrm{H}-5,46-50$ & 172.81 & 94.61 & 2.1 & 1.0 & 32.0 & 0 \\
\hline
\end{tabular}

